\title{
A GRID-BASED GIS APPROACH TO REGIONAL FLOOD DAMAGE ASSESSMENT
}

\author{
Ming-Daw Su \\ Professor, Department of Bioenvironmental Systems Engineering, National Taiwan University, Taipei, Taiwan, 10616, \\ sumd@ntu.edu.tw \\ Jui-Lin Kang \\ Ph.D. Candidate, Department of Bioenvironmental Systems Engineering, National Taiwan University, Taipei, Taiwan \\ 10616. \\ Ling-Fang Chang \\ Ph.D. Candidate, Department of Bioenvironmental Systems Engineering, National Taiwan University, Taipei, Taiwan \\ 10616.

\section{Albert S Chen} \\ Senior Assistant Research Fellow, National Science and Technology Center for Disaster Reduction 3F, No.106, Sec. 2, \\ Hoping E. Rd., Taipei, Taiwan 10616.
}

Follow this and additional works at: https://jmstt.ntou.edu.tw/journal

Part of the Civil and Environmental Engineering Commons

\section{Recommended Citation}

Su, Ming-Daw; Kang, Jui-Lin; Chang, Ling-Fang; and Chen, Albert S (2005) "A GRID-BASED GIS APPROACH TO REGIONAL FLOOD DAMAGE ASSESSMENT," Journal of Marine Science and Technology. Vol. 13: Iss. 3, Article 4. DOI: $10.51400 / 2709-6998.2125$

Available at: https://jmstt.ntou.edu.tw/journal/vol13/iss3/4

This Research Article is brought to you for free and open access by Journal of Marine Science and Technology. It has been accepted for inclusion in Journal of Marine Science and Technology by an authorized editor of Journal of Marine Science and Technology. 


\section{A GRID-BASED GIS APPROACH TO REGIONAL FLOOD DAMAGE ASSESSMENT}

\section{Acknowledgements}

This study is part of the research result of the project NSC93-2625-Z-002-035 financially supported by the Taiwan National Science Council. 


\title{
A GRID-BASED GIS APPROACH TO REGIONAL FLOOD DAMAGE ASSESSMENT
}

\author{
Ming-Daw Su*, Jui-Lin Kang**, Ling-Fang Chang**, and Albert S. Chen***
}

Key words: grid-based, GIS, flood damage, risk.

\begin{abstract}
Regional flood risk assessment is the base for a sound and comprehensive risk planning or management. The regional flood loss is the sum of the damages in all the flooded parcels. The data involved in this process are multifarious and difficult to establish and maintain especially in the developing countries that suffer most often from the flood hazard. A grid-based GIS approach to regional flood damage assessment is proposed in this paper. Aggregated census data that are relatively available were used instead of the data at parcel level. An algorithm was proposed to disaggregated these aggregated census data into spatially uniform grid cells as being used in most flood hazard simulation models. Land use or zoning information was used in the disaggregation process for capture of the realistic spatial distribution of the economic activities. The exceedance probability curve of the flood loss was used to integrate the damage assessments of individual flood event for a full probability range presentation of the flood risk. A framework was also developed for coupling the regional flood risk with the risk planning and management through the use of exceedance probability curve and annual average flood loss concepts. Shih-Jr City in northern Taiwan was used as a study area for the demonstration of the proposed algorithm.
\end{abstract}

\section{INTRODUCTION}

Each year natural hazards, such as earthquake, typhoon, flood, and debris flow etc., cause tremendous loss of properties and human lives not only in Taiwan but also around the world. A proper hazard management becomes a vital base for the society prosperity. Hazard and risk assessments are the starting points for defining actions that communities can take to reduce economic losses, social impacts and casualties from

Paper Submitted 12/15/04, Accepted 03/30/05. Author for Correspondence: Ming-DawSu.E-mail: sumd@ntu.edu.tw.

*Professor, Department of Bioenvironmental Systems Engineering, National Taiwan University, Taipei, Taiwan, 10616.

**Ph.D. Candidate, Department of Bioenvironmental Systems Engineering, National Taiwan University, Taipei, Taiwan 10616.

***Senior Assistant Research Fellow, National Science and Technology Center for Disaster Reduction 3F, No.106, Sec. 2, Hoping E. Rd., Taipei, Taiwan 10616. natural hazards [13]. Sufficient understating of the hazard and risk can support the decision maker in choice of engineering or non-engineering measures for flood damage reduction [22]. There may be different measures that can be taken for hazard management in a region, such as land use planning and management, construction of engineering structures and flood monitoring or warning systems, etc. The effectiveness of these alternatives can be more properly evaluated if the comparisons are based on the risk reductions from the implementation of that measure [10]. This can be done using a with-and-without analysis by assessing the risk before and after the measure. Risk can be defined as the possibility of loss or injury [24] and can be expressed as Eq. (1). [4]

$$
R=H \times V \times E
$$

Where $R$ : Risk

$H$ : Hazard, the probability of a potentially destructive phenomenon occurs within a determined period and region.

$V$ : Vulnerability, the degree of loss sustained by a particular element or group of elements exposed to risk due to a natural phenomenon of certain intensity.

$E$ : Exposure, the element at risk such as population, property or other human activities.

Flood as a major and frequently occurred natural hazard, its risk can also be assessed using the above equation. Flood hazard maps are the first thing to be done in flood risk assessment [26]. Flood hazard can be assessed by field survey, remote sensing [6, 19, 20, 21] during or after an event or by computer modeling [15].

Other than the flood hazard, vulnerability information is also needed for risk assessment according to Eq. (1). The concept of using stage-damage curves for flood vulnerability study was firstly proposed by G.F. White [31]. The stage-damage curve describes the relation of flood damages to flood depths (stages). 
Although the stage-damage curve in general didn't consider the effects of flow speed, period of inundation, and sedimentation load and may need improvements [23], this concept were still used intensively for flood damage assessment [1, 2, 3, 5, 7, 8, 9, 27]. Most of the studies mentioned focused on the constructions of the stage-damage curves related to a specific class of different human activities or land use categories. These curves can be used to estimate the damage of an object (a family house, a manufacturing factory or a land parcel) under a specific flood event. Since the hazard management studies are usually on a regional basis instead of a single object, an up-scaling from a point estimate to a regional one is necessary. This paper is to set up a framework for regional flood damage assessment which is the base of practical hazard management. The Shih-Jr City and its vicinity, an urban area in northern Taiwan near City of Taipei, is taken as a case study to demonstrate the proposed methodology.

\section{REGIONAL FLOOD DAMAGE ASSESSMENT}

Since human activities and the flood depths are not homogenous across the flood area, the spatial variations of social and economic activities and the flood hazard have to be taken into account in the assessment of the regional flood damage. There are two approaches, the parcel-based and the grid-based, to handle this spatially distributed situations. The parcel-based approach keeps detail information of the socio-economic activities, e.g. the family housing, factories and stores, etc. at parcel level. The respective stage-damage curve is then applied to each parcel with the estimated flood depth at that point for its damage assessment [5]. The regional damage is the loss sum of all parcels for the entire flooding area. The data needed for this approach including land parcel maps and socio-economic activities on each parcel. These data are multifarious and difficult to establish and maintain. This is especially true in the developing countries that suffer most often from the natural hazards like flood.

On the other hand, the grid-based approach is based on a grid data model which divides the region into grid cells of equal area. The socio-economic activities are considered to be homogeneous within each cell and are aggregated into a single value and assigned to that cell. The data needed for this model can be derived from the aggregated census data that is more available than the individual ones. The flood damage is then estimated from the average flood depth and the aggregated census data for each cell using the stage-damage curve [7]. The regional flood damage is calculated from the summation of loss estimation of each cell. This paper focuses on the development of a grid-based regional flood dam- age assessment model. The grid-based approach is taken because parcel data are difficult to establish or access due to the concern of privacy. The aggregated census data are easier to get even in the developing countries. Another reason for employing the grid-based model in this study is because flood hazard potential maps generated from computer modeling are usually in grid data format.

\section{Hazard analysis: flood potential maps}

Hazard analysis is to derive the hazardous potential under different scales of event. In the case of flood, the flood potential maps are to be derived under flood events of different return periods. The development of flood potential maps requires a two-dimensional distributed watershed model to estimate flood depths. Each watershed was divided into upstream mountainous catchments and a downstream alluvial plain with the assistance of geographical information systems (GIS). The HEC-1 model of US Corps of Engineers was used to compute the discharges of the mountainous catchments. An one-dimensional dynamic channelflow routing was performed for the main channel flow computation, whereas a two-dimensional overland-flow routing was used for surface inundation simulation of the alluvial plain. For the urban regions with detailed sewer drainage system information, the Storm Water Management Model [17, 18] was applied for sewer flows routing.

The HEC-1 model developed by U.S. Army Corps of Engineers Hydrologic Engineering Center in 1992 [30] was applied to the upstream mountainous catchments of the watershed to determine the surface runoff resulting from effective rainfall. The movement of water can be characterized by two components in the area: the land surface runoff component representing the movement of water over the land surface and into stream channels, and the stream routing component denoting flood wave propagation in a channel. The resulting discharges were set as the upstream boundary conditions for one-dimensional channel flow or twodimensional overland flow routing.

A series of studies on the numerical flood model in Taiwan have been conducted $[14,5,16]$. It was concluded in those studies that a two-dimensional noninertia wave model could accurately simulate the overland-flow characteristics of floodplains due to its slow flow dynamics. Based on the assumption that accelerations of the water flow on the land surface are small compared to gravity and friction, the inertial terms in the St. Venant equation are neglected. The continuity and depth-averaged shallow water equations can be written as follows: 


$$
\begin{aligned}
\frac{\partial d}{\partial t}+ & \frac{\partial[(1-\beta) u d]}{\partial x}+\frac{\partial[(1-\beta) v d]}{\partial y} \\
& =q_{\text {source }}(x, y, t)-q_{\text {sink }}(x, y, t) \\
-\frac{\partial h}{\partial x} & =S_{f x}+\frac{\left[q_{\text {source }}(x, y, t)\right] u}{g d} \\
-\frac{\partial h}{\partial y} & =S_{f y}+\frac{\left[q_{\text {source }}(x, y, t)\right] v}{g d}
\end{aligned}
$$

Where,

$d=$ The water depth,

$\beta=\sqrt{A_{b} / A}$ Detaining ratio which represents a linear ratio of building area to the total area of interest;

$u$ and $v$ are the velocity components in the $x$ and $y$ directions, respectively;

$h=d+z$ the water surface elevation;

$S_{f x}=\left(n^{2} u \sqrt{u^{2}+v^{2}}\right) /\left(d^{4 / 3}\right)$ and

$S_{f y}=\left(n^{2} v \sqrt{u^{2}+v^{2}}\right) /\left(d^{4 / 3}\right)$ are the friction slopes

along the $x$ and $y$ directions, respectively

$q_{\text {source }}(x, y, t)=$ the rate of water entering ground surface per unit area, including the surcharges from manholes, the upstream catchments inflows and lateral inflows from channels;

$q_{\sin k}(x, y, t)=$ the rate of water leaving ground surface per unit area, including the drainages through inlets to sewers and the lateral outflow to channels.

The urban drainage systems are also considered. To simulate the flow interactions between the sewer system and the ground surface, the drainage through

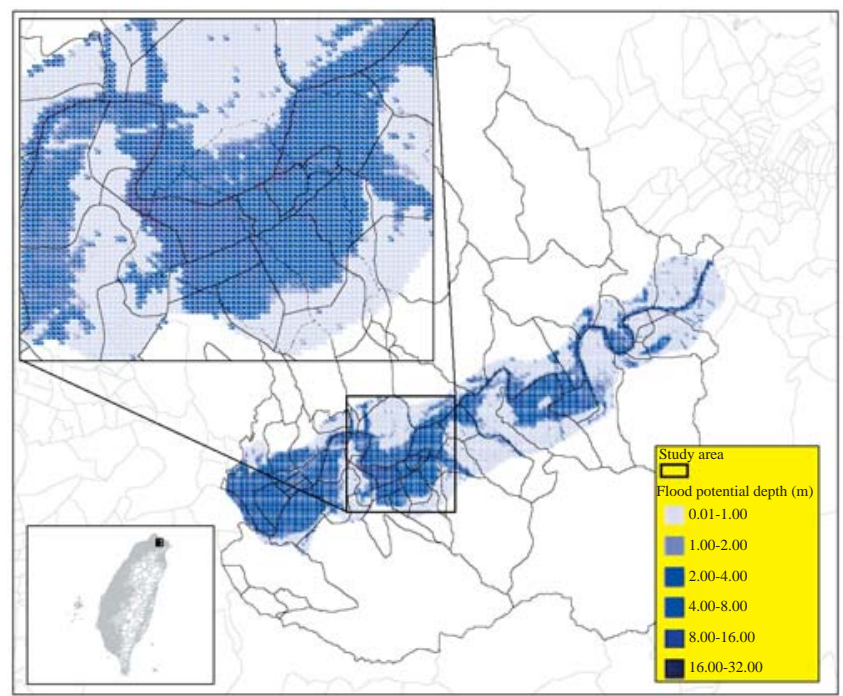

Fig. 1. Flood hazard map from computer modeling. inlets to the sewer systems and the overflow from the surcharged manholes to ground surface is used for model linkages between the overland flow model and sewer routing model. The former is treated as the sink and the latter as the source in the two-dimensional model. Eqs. (2) to (4) are solved by a finite difference numerical scheme, named alternating direction explicit (ADE), which allows an initial condition with zero water depth and velocity [15]. A sample flood potential map is shown as in Figure 1.

\section{Vulnerability analysis: loss functions}

For assessment of the risk, loss or damage must be estimated after the hazard analysis is done. Stagedamage curves, also known as "flood loss functions" [7, $25,28,31,32]$ were used for this purpose in this study. A stage-damage curve depicts the relationship of damage varied with the flood depth (or stage). Individual curves are usually built for different human activities.

The loss function characteristics may be highly affected by the nature of human activities. A loss function usually relates to a specific type of land use zoning or economic activity and presents information on the relationships of damages to the flood depths. Human activities were classified into residential, commercial and industrial in this study. Activities in residential area are further subdivided into single-family and multiple-family dwellings, car and motorcycle, and utility facilities like the power distribution units which are usually located at the basement and are often suffering severe damages during a flood. Other economic activities are categorized as manufacturing, wholesaler, retailer, service, and public facilities. The former four are further divided into large and small scale. The flood damage data used to derive the loss functions were collected from a field survey in the frequently flooded area and the damage claim information filed with the Internal Revenue Service for tax deduction. The data are recorded in a per-household or per-firm bases. The sizes of a household are rather uniform in term of floor square footages, the numbers and kinds of furniture and appliances, etc. But commercial and industrial activities may vary considerably in scale. A manufacturing factory may be a couple of times larger than the others. A supermarket is also bigger in size than a neighborhood convenience store. Since the flood damage claims are usually filed by firm, the scale difference may become an important factor when relating the flood damages to the stages for activities other than the residential one. The loss functions for the manufacturing, wholesale, retail and service are then further subdivided into large and small scales categories to handle this problem. [29]. The characteristics of each activity 
category are summarized as follows.

Single and Multiple Family Dwellings: One household occupies a whole building in the single family residential zone, while each floor is used by an individual household, like in the apartment, in the multiple family residential one. The flood loss characteristics are quiet different for these two residential types because some valuable assets may be moved to the higher floor to prevent being damaged in advanced or even right before the hit of a flood in single family residential.

Vehicles: Vehicles such as motorcycles and cars are one of the major sources for flood damages in residential area. The relationships of the damages versus the flood depth were derived from the field survey data and the interviews with the mechanics, car dealers, and the service department of the major car manufacturing companies.

Manufacturing: The manufacturing may have raw material, machineries, product or semi-finished goods.

Wholesale: The wholesalers usually stock their merchandises higher than the retailers whose goods are usually under an easy to reach height. The damage may increases with the flood depth up to the ceiling although it may not be linearly changed.

Retailer: Because most of the merchandises are stocked under certain height for easy access, the flood damage for a retailer will increase rapidly as the flood depth increases, but may become steady as the inundation raises beyond certain depth.

Service: The service firms like banks or offices are usually equipped with office furniture and business equipments like computer, fax and copy machine.

Curves for these different activity categories as shown in Figures 2-5, were developed in a previous study of the authors [29] based on flood damage data collected after Typhoon Nari that caused a major damage in the Taipei Metropolitan in 2001.

\section{Exposure analysis}

The flood damage is assessed by using the hazard information (flood depth), the loss functions and the exposure data. The exposure is defined as the human activities affected by the hazardous event. The flooding area shown in the flood hazard map doesn't reveal the houses, factories or firms covered underneath. The exposure analysis is to find out the economic activities covered by the flood. The census data were used in this study with the flood hazard map for exposure analysis. The flood hazard map is a raster based map (as shown in Figure 1) which divided the area into small cells using an uniform grid and recorded the flood depths for each cell. The censuses for demographic, commercial, industrial, and agricultural activities are done every ten

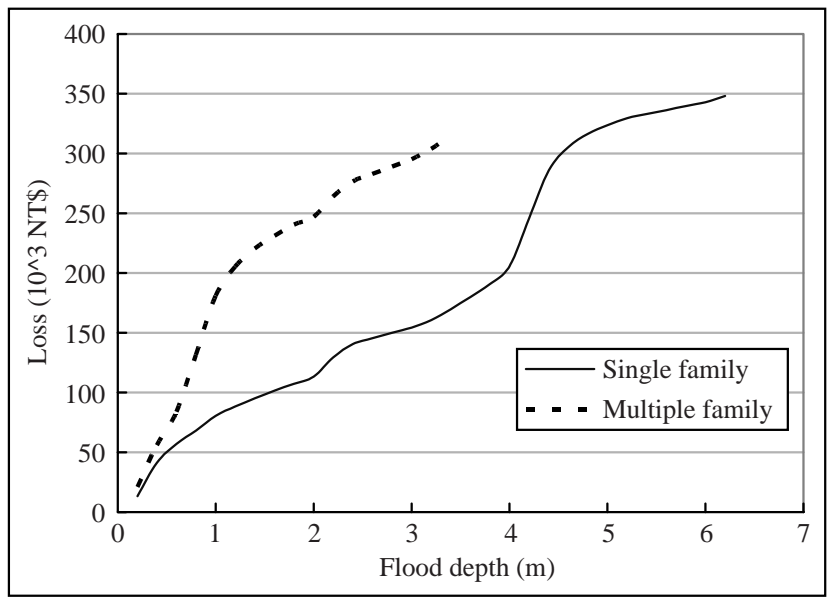

Fig. 2. Stage-damages curves for residential.

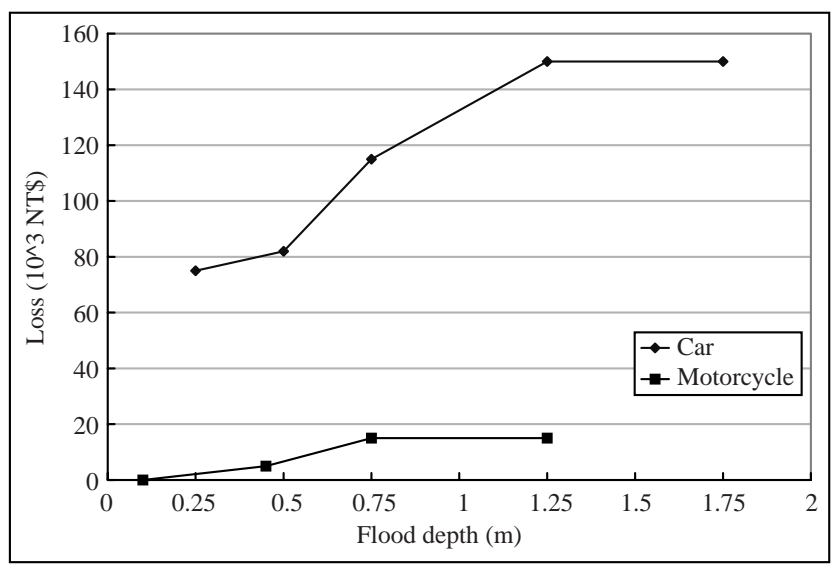

Fig. 3. Stage-damages curves for motorcycle and car.

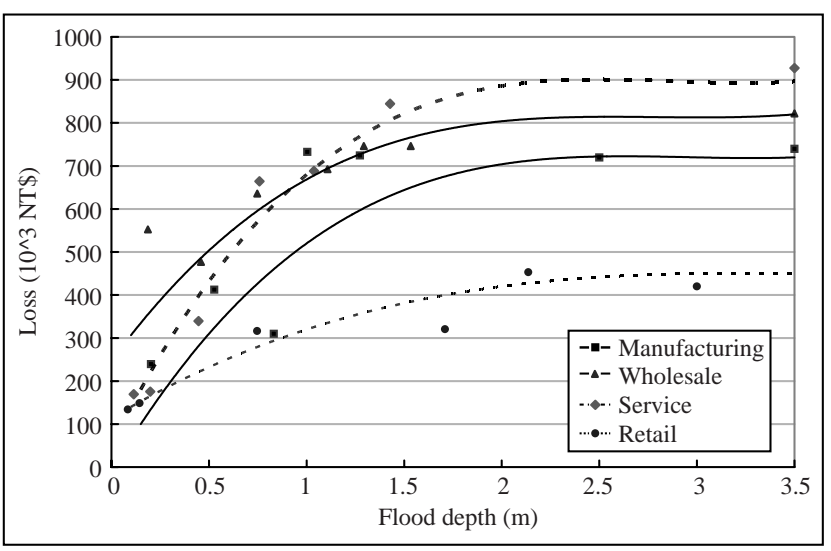

Fig. 4. Stage-damages curves for small scale commercial and industrial. 
or five years in Taiwan to track the national development. Although 1 information of individual activity is gathered in the census processes, the data set are usually provided in a form aggregated within some administration boundary such as census tract for privacy concern. But for estimation of the activities in each cell of the flood hazard map, these aggregated data have to be decomposed into the equivalent spatial units. Instead of using the average scheme by dividing the total activities with the area, land use and zoning information are used as a reference in the decomposition process in this study. Some area such as river channel, pond, park, highway, etc. will not have any economic activities on it and will be excluded during this decomposition process for the aggregated census data. The results using this algorithm, as shown in Figure 6, will exhibit more realistic spatial distribution details of the regional economic activities.

\section{Regional flood damage and risk assessments:}

The regional flood damage assessment, instead of the one for a single house or firm, is an important step for regional risk management. Flood damage can be calculated cell by cell using the flood depths, exposure information and the respective loss functions. The regional damage caused by a flood event can then be assessed by summing up the damage of all the cells within the region. The risk as shown in Eq. (1) is defined as the damage multiplied by the occurrence probability. A set of flood potential maps with different occurrence probability, instead of one for a single event, can be prepared for the region for full range knowledge of the risk. The risk of each flood event can first be calculated by multiplying the estimated damage of that event with its occurrence probability. This risk for specific event is not adequate for regional flood risk planning and management. The Average Annual Flood

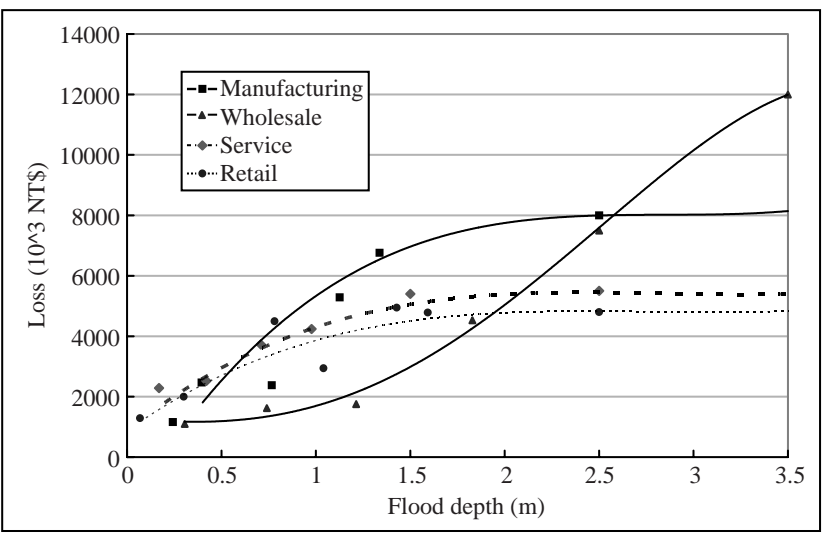

Fig. 5. Stage-damages curves for large scale commercial and industrial.
Loss $(A A F L)$ caused by flood hazard [11] was used in this study for regional flood risk assessment. The exceedance probability curve (EP curve) for flood damage of a region can be constructed by using the damages of each simulated event and its respective exceedance probabilities. The $A A F L$ can be defined as the area under the $E P$ curve of flood damage as shown in Figure 7 and can be calculated by Eq. (5) [1]. The $A A F L$ estimation can also be approximated discretly by splitting the curve into smaller discrete segments [12].

$$
A A F L=\int x f(x) d x
$$

Where: AAFL: Average Annual Flood Loss $x$ : Damage of a flood event $f(x)$ : The probability density function of $x$

\section{CASE STUDY}

The Shih-Jr City and vicinity, an urban area in northern Taiwan near Taipei Metropolitan, was chosen as a case study to demonstrate the proposed framework for regional flood risk assessment. The city with an area of 127 square kilometers is passed through by Kee-Lung River. As displayed in Figure 8, the terrain map shows most of the area other than that near the river is slope

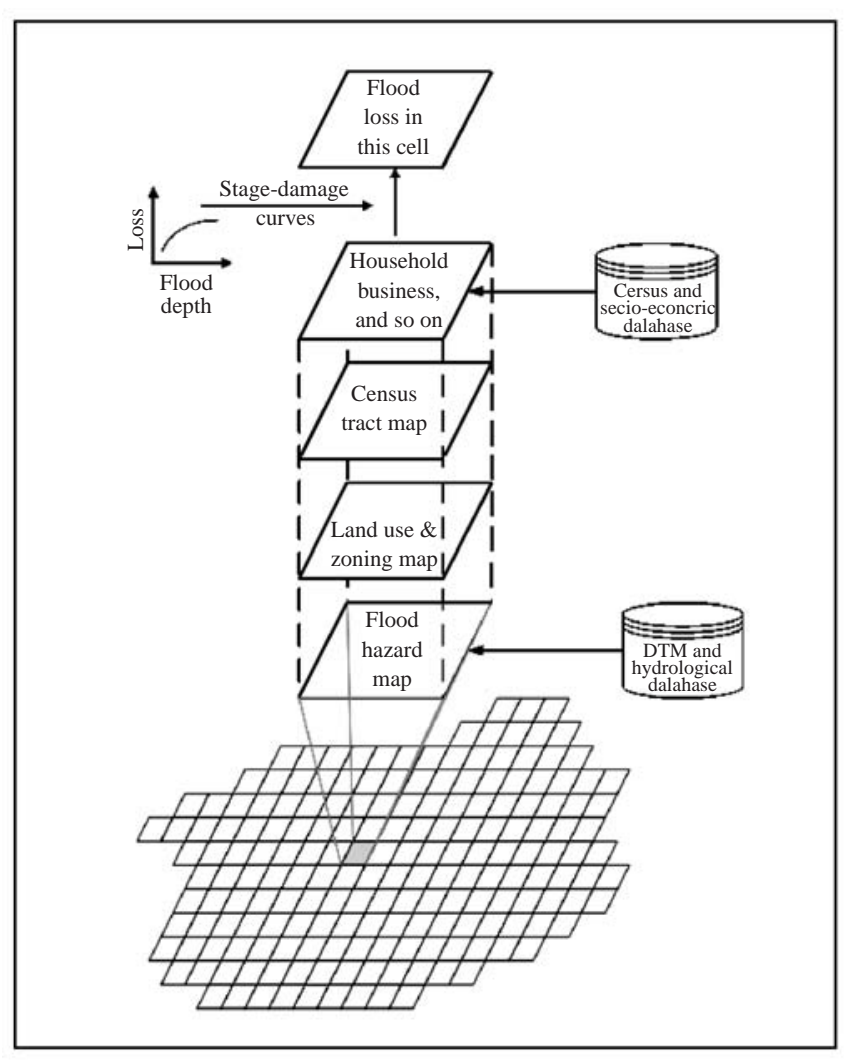

Fig. 6. Algorithm for decomposition of aggregated census data. 
land. The population and commercial and industrial activities of the city grow rapidly for the last two decades. The intensity of land use and development increased rapidly so that this area lately suffers from frequent floods.

To assess the flood risk for the study area, hazard analysis was first done and flood potential maps under different probabilities of occurrence were generated with a grid resolution of 40 meters by 40 meters. Flood events with return period of 2, 5, 10, 25, 50, 100 and 200 years were used for this flood hazard analysis to cover the probable situations in a more completed sense. The resulting flood potential maps for each simulated events were developed and are shown as in Figure 9.

Spatial information was gathered for this area including land use, zoning, administrative boundary, and digital terrain. The related census data such as demographic, vehicles, commercial and industrial activities were collected for exposure analysis. These

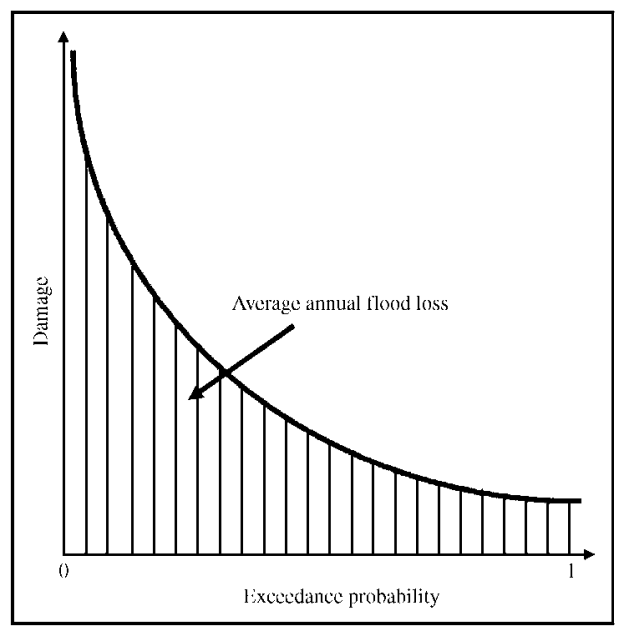

Fig. 7. Exceedance probability curve for flood damage.

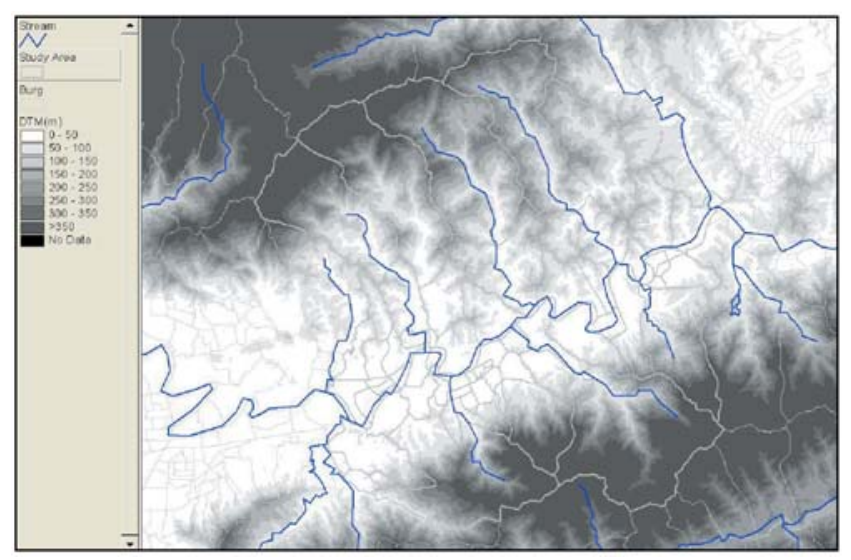

Fig. 8. The topography of the study area. collected census data are in a form aggregated by census tract or $L E E$, the basic unit of city administration. These aggregated data were disaggregated into the 40 meters by 40 meters cells to be compatible with the previously generated flood potential maps. Land use and zoning information was used to assist this disaggregation process. Instead of using the whole area to distribute the aggregated census data, area that cannot be used for economic activities, such as river channel, road, park and other public facilities, were excluded to avoid apportioning data onto it.

The census data for commercial and industrial activities are sub-grouped into manufacturing, wholesale, retail, and service using their Standard Industrial Codes (SIC). The related loss functions were applied to these disaggregated data with the flood depths for damage assessment for each cell and each category. The results of damage assessment can be presented as maps (Figure 10) or in tabular form for each flood event. As a comparison, the flood damages were also estimated at the basic city administrative unit level ( $L E E)$ using the aggregated census data and the results are displayed as shown in Figure 11. From the two maps shown in Figure 10 and Figure 11, the proposed cellbased algorithm displays more details for the spatial variation of the flood damage. This realistic spatial information will enable the regional planners or risk managers to identify which portion of the city is of higher risk than the other and needs more intention in the risk planning and management process.

The regional flood damages estimated for each flood event were then associated with its occurrence probability to construct the EP curve for flood risk of

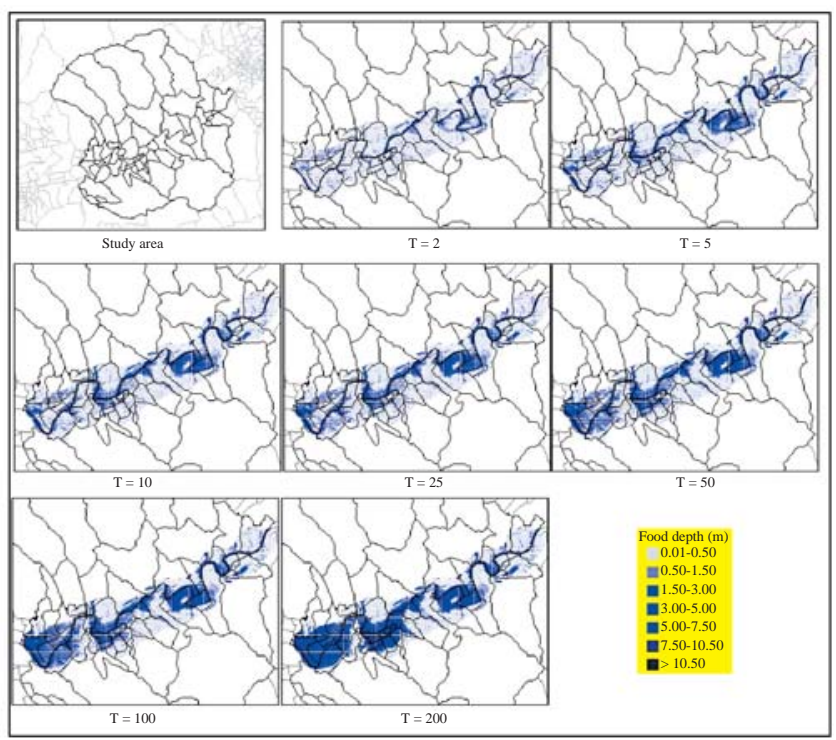

Fig. 9. Flood potential maps. 
the city (as shown in Figure 12). The Average Annual Flood Loss was estimated by integrating the area under the exceedance probability curve. This AAFL can be used as a basis for evaluation of the flood management measures through with-and-without analysis. For example, a flood mitigation project, say a plan to raise the levee height, is proposed. The above algorithm can be repeated for a scenario with the proposed project implemented and the corresponding $A A F L$ can be estimated. The difference of the $A A F L$ with and without the project will be the annual benefit of the project implementation. Together with the annual cost esti-

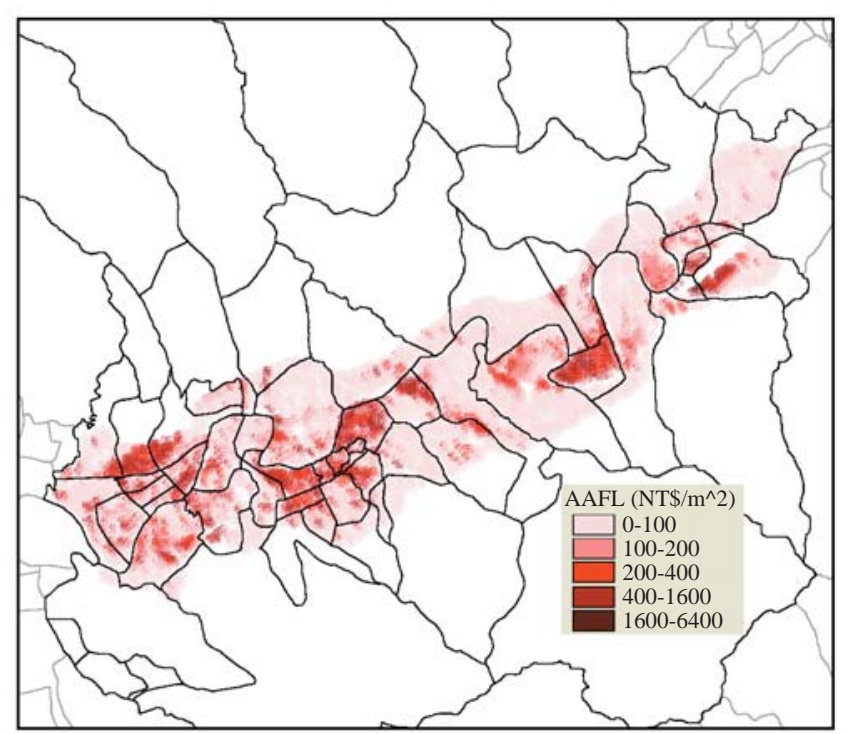

Fig. 10. Grid-based regional flood risk map.

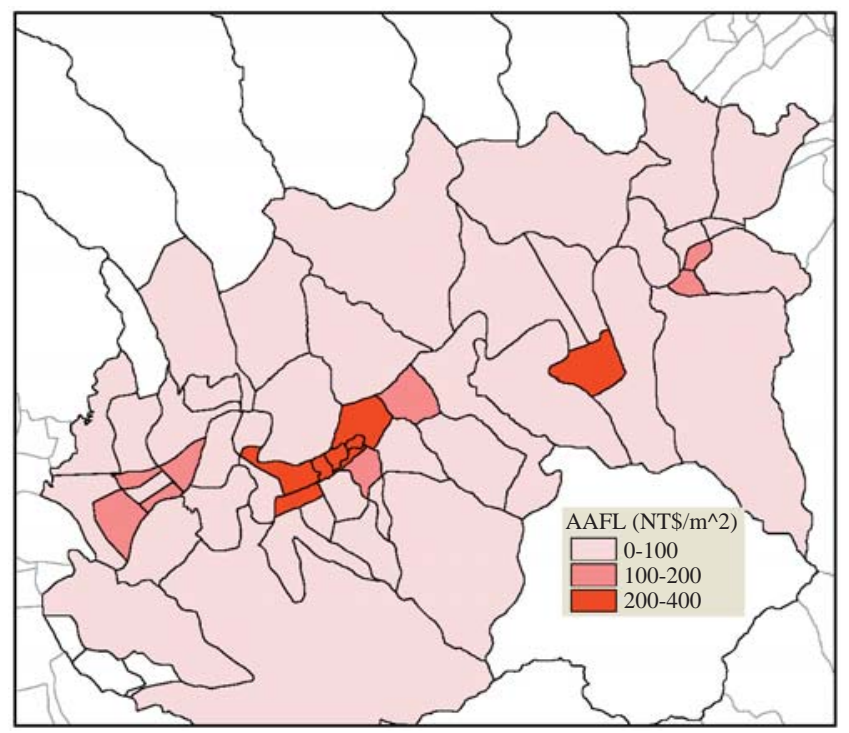

Fig. 11. Polygon-based regional flood risk map. mated for implementing the project, the planner can better justify if the project is economically viable.

\section{DISCUSSIONS AND CONCLUSIONS}

1. Regional flood risk assessment is the vital part for risk management. Although a parcel-based flood damage assessment is more accurate but it is also not very practical because it needs gigantic and detailed information at the parcel level. The grid-based approach uses only aggregated census data that are comparatively more available. A disaggregation algorithm was proposed to decompose the aggregated census data down to a smaller grid cell data model for matching with the flood hazard maps generated from flood simulation models. Spatial information such as land use, zoning, and terrain were used as background support for a more realistic decomposition.

2. Traditionally, administrative units were used as the operational unit for the flood damage assessment. The detailed spatial variation of flood hazard and damage are overlooked as shown by the example shown in Figure 11. This approach also suffers from a classical problem of geography: the modifiable area unit problem (MAUP). The spatial patterns under different scale may vary considerably. The same example shown in Figure 11 may vary if a different spatial unit is used as shown in Figure 10. Although the grid-based approach cannot get around the MAUP, but the MAUP effects decrease considerably as the cell size becomes smaller. The problem will diminish as the cell size approaching the average parcel size.

3 . The concept of exceedance probability curve (EP curve) was used to establish a regional risk assessment at full probability range. Average Annual Flood Loss (AAFL) combined with the with-and-without analysis was also proposed for better economic evalu-

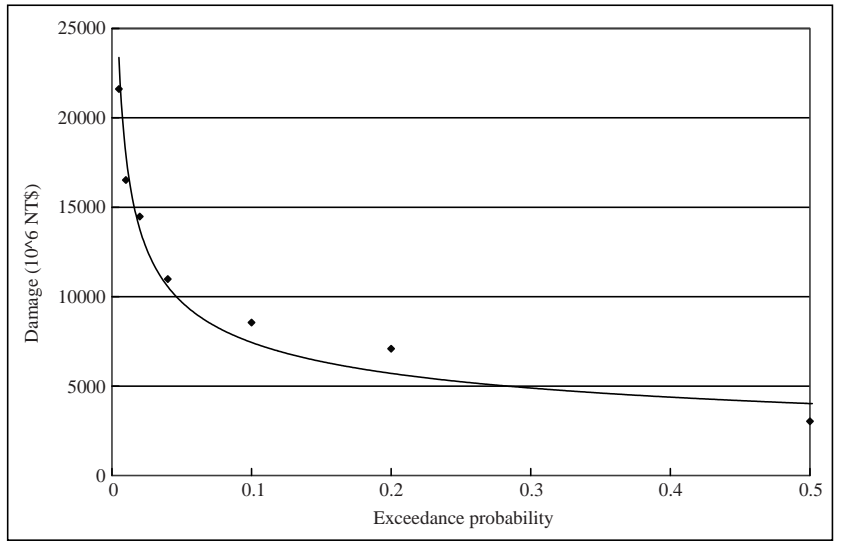

Fig. 12. Exceedance probability curve of flood damage in Shi-Jr City. 
ation among flood mitigation measures.

4. The AAFL can be calculated for each grid cell instead of the region as a whole. The resulting map can be taken as Risk Map showing the spatial variation of average flood risk in the region. A sample risk map is shown in Figure 10 for the study area. With the information of risk spatial variation, current land use can be reviewed and a more reasonable land use pattern can be proposed for effective flood risk mitigation.

The grid-based approach and the regional risk assessment algorithm proposed in this study are practical because only the aggregated census information that is generally available even in developing countries is used. Also because the structured characteristic of the algorithm and the census database, the whole process can be programmed as an automated model for more effective regional flood risk management in the future.

\section{ACKNOWLEDGEMENTS}

This study is part of the research result of the project NSC93-2625-Z-002-035 financially supported by the Taiwan National Science Council.

\section{REFERENCES}

1. Arnell, N.W., "Expected Annual Damage and Uncertainties in Flood Frequency Estimation," J. Water Res. Pl. Management, Vol. 115, No. 1, pp. 94-107 (1989).

2. Berning, C., Viljoen, M.F., and DuPlessis, L.A., "Loss Function for Sugar-cane: Depth and Duration of Inundation as Determinates of Extent of Flood Damage," Water SA, Vol. 26, No. 4, pp. 527-530 (2000).

3. Berning, C., DuPlessis, L.A., and Viljoen, M.F., "Loss Function for Structural Flood Mitigation Measures," Water SA, Vol. 27, No. 1, pp. 35-38 (2001).

4. Besio, M., Ramella, A., Boobe, A., Colombo, A., Olivieri, C., and Persano, M., "Risk Maps: Theoretical Concepts and Techniques," J. Hazard. Mater., Vol. 61, pp. 299304 (1998).

5. Boyle, S.J., Tsanis, I.K., and Kanaroglou, P.S., "Developing Geographic Information Systems for Land Use Impact Assessment in Flooding Conditions," J. Water Res. Pl., Vol. 124, No. 2, pp. 89-98 (1998).

6. Brivo, P.A., Colombo, R., Maggi, M., and Tomasoni, R., "Integration of Remote Sensing Data and GIS for Accurate Mapping of Flooded Areas," Int. J. Remote Sens., Vol. 23, No. 3, pp. 429-441 (2002).

7. Dutta, D., Herath, S., and Musiake, K., "A Mathematical Model for Flood Loss Estimation,” J. Hydrol., Vol. 277, pp. 24-49 (2003).

8. Goldman, D., "Estimating Expected Annual Damage for Levee Retrofits," J. Water Res. Pl., Vol. 123, No. 2, pp.
89-94 (1997).

9. Grigg, N.S., Water Resources Management, McGrawHill, New York (1996).

10. Gupta, S., Javed, A., and Datt, D., "Economics of Flood Protection in India," Nat. Hazards, Vol. 28, pp. 199-210 (2003).

11. Hardison, C.H. and Jennings, M.E., "Bias in Computed Flood Risk," J. Hydr. Div-ASCE, Vol. 98, No. 3, pp. 415427 (1972).

12. Helweg, O.J., Water Resources Planning and Management, John Wiley \& Sons, Inc., New York (1985).

13. Hays, W.W., "Hazard and Risk Assessment in the United States," Episodes, Vol. 14, No. 1, pp. 7-12 (1991).

14. Hsu, M.H., Lai, J.S., and Yen, C.L., "Two-dimensional Inundation Model for Taipei City," Proceedings of the Fifth International Conference on Urban Storm Drainage, Osaka, Japan (1990).

15. Hsu, M.H., Chen, S.H., and Chang, T.J., "Inundation Simulation for Urban Drainage Basin with Storm Sewer System," J. Hydrol., Vol. 234, No. 1-2, pp. 21-37 (2000).

16. Hsu, M.H., Chen, S.H., and Chang, T.J., "Dynamic Inundation Simulation of Storm Water Interaction between Sewer System and Overland Flows," J. Chin. Inst. Eng., Vol. 25, No. 2, pp. 171-177 (2002).

17. Huber, W.C., "Model for Storm Water Strategies," The APWA Reporter, Vol. 42, No. 5, pp. 10-14 (1975).

18. Huber, W.C. and Dickinson, R.E., Storm Water Management Model User's Manual Version 4 (EPA/600/388/001a), U.S. Environmental Protection Agency, Athens, GA (1988).

19. Islam, M.K. and Sado, K., "Flood Hazard Assessment in Bangladesh Using NOAA AVHRR Data with Geographical Information System," Hydrol. Proc., Vol. 14, pp. 605-620 (2000a).

20. Islam, M.K. and Sado, K., "Development of Flood Hazard Maps of Bangladesh Using NOAA-AVHRR Images with GIS," Hydrolog. Sci. J., Vol. 45, No. 3, pp. 337-355 (2000b).

21. Islam, M.K. and Sado, K., "Development Priority Map for Flood Countermeasures by Remote Sensing Data with Geographic Information System," J. Hydro. Eng., Vol. 7, No. 5, pp. 346-355 (2002).

22. James, L.D. and Hall, B., "Risk Information for Floodplain Management," J. Water Res. Pl., Vol. 112, No. 4, pp. 485-499 (1984).

23. McBean, E.A., Jack, G., Michael, F., John, D., and Ralph, M., "Adjustment Factors for Flood Damage Curves," J. Water Res. Pl., Vol. 114, No. 6, pp. 635-646 (1988).

24. Merriam-Webster, http://www.m-w.com/ (2004).

25. Penning-Rowsell, E.C. and Chatterton, J.B., The Benefits of Flood Alleviation: A Manual of Assessment Techniques, Gower Press, Aldershot, England (1977).

26. Plate, E.J., "Flood Risk and Flood Management," $J$. 
Hydrol., Vol. 267, pp. 2-11 (2002).

27. Sacramento and San Joaquin River Basins, Post-Flood Assessment, U.S. Army Corps of Engineers, Sacramento, CA (1999).

28. Smith, D.I., "Flood Damage Estimation-A Review of Urban Stage-Damage Curves and Loss Functions," Water SA, Vol. 20, No. 3, pp. 231-238 (1994).

29. Su, M.D., Investigation and Analysis on the Flood Damages in Taipei Metropolitan (Project Report), Taipei City Government, Public Works Department, Taipei,
Taiwan (2003).

30. U.S. Army Corps of Engineers Hydrologic Engineering Center, HEC-1 Hydrograph Package, Water Resources Support Center, Davis, CA (1992).

31. White, G.F., Human Adjustment to Floods (Research Paper No. 29), University of Chicago, Department of Geography, Chicago, IL (1945).

32. White, G.F., Choice of Adjustments to Floods (Research Paper No. 93), University of Chicago, Department of Geography, Chicago, IL (1964). 